III Encuentro Bienal de Investigación y Postgrado 2016 / Ciencia y Tecnología III Research and Postgraduate Biennial Encounter 2016 / Science and Technology

\title{
T2 - Bioprospección de hiperparásitos de Hemileia vastatrix en Guatemala
}

\author{
Soren S. Ramírez-Barillas, José M. Escobar-Sandoval, Gustavo Álvarez-Valenzuela* \\ Facultad de Agronomía, Universidad de San Carlos de Guatemala
}

*Autor al que se dirige la correspondencia: gusialvarez@yahoo.com

\section{Resumen}

$\mathrm{L}$ a bioprospección de agentes de control biológico es una actividad primaria en la búsqueda de alternativas

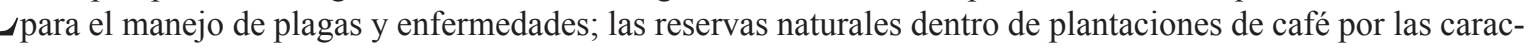
terísticas de biodiversidad son aptas para albergar diversidad microbiana y entre ellos agentes biocontroladores. El estudio se realizó en 10 fincas con reservas naturales con café, cinco en el departamento de Guatemala, cuatro en Sacatepéquez y una en Chimaltenango, los muestreos se realizaron en época seca y lluviosa; se obtuvo, documentó y determinaron en laboratorio los agentes hiperparásitos: Cladosporium hemileiae Steyaert, y Lecanicillium lecanii (Zimmerm.) Zare \& W. Gams y además un insecto micófago Mycodiplosis sp. (Diptera, Cecidomyiidae). Se evaluaron las cepas de los hongos hiperparásitos con el índice de velocidad de crecimiento micelial (IVCM) y producción de conidiosporas. Se estableció que las mejores cepas de $C$. hemileiae fueron: Morán época seca parte baja, San Sebastián época seca y Guardabarranca parte alta; para L. lecanii fueron: San Sebastián época seca y Corral Viejo estación lluviosa parte baja.

Palabras claves: Biocontroladores, roya, control biológico, prevalencia, hiperparásito

\begin{abstract}
$\mathrm{B}^{\mathrm{i}}$ ioprospecting biological control agents is a primary activity in the search for alternatives for pest and diseases management in natural reserves of coffee plantations with a biodiversity characteristics are suitable to host microbial diversity. The study was conducted in 10 farms with voluntary private natural reserves: five in Guatemala, four in Sacatepéquez and one in Chimaltenango, sampling was carried out during the dry and rainy seasons. The hyperparasites were obtained, documented and determined: Cladosporium hemileiae Berk. \& Br., and Lecanicillium lecanii (Zimmerm.) Zare \& W. Gams., and a mycophage insect Mycodiplosis sp. (Diptera, Cecidomyiidae). After analysis of mycelial growth rate (IVCM) and conidiaspores production, it was established that the best strains of C. hemileiae, were: Moran dry season low part, San Sebastián dry season and Guardabarranca high part; for $L$. lecanii, were: San Sebastian dry season and Corral Viejo wet season low part.
\end{abstract}

Keywords: Biocontrol, rust, biological control, prevalence, hyperparasites sobre protección a los derechos de autor, con criterio especificados en la licencia Creative Commons (CC BY-NC-SA 4.0) 